\title{
PENGARUH PREMI, KLAIM DAN HASIL INVESTASI TERHADAP LABA PADA PERUSAHAAN ASURANSI JIWA SYARIAH DI INDONESIA TAHUN 2014-2019
}

\author{
Nia Anggraina Zen ${ }^{1}$ Gusganda Suria Manda ${ }^{2}$
}

\section{Article history:}

Submitted:

4 Agustus 2020

Revised:

28 September 2020

Accepted:

1 Oktober 2020

\section{Keywords:}

Premiums;

Claims;

Investment Returns;

Profit.

\section{Kata Kunci:}

Premi;

Klaim;

Hasil Investasi;

Laba.

\section{Koresponding:}

Fakultas Ekonomi, Universitas

Singaperbangsa Karawang, Karawang, Indonesia Email:nia.anggraina16195 @ student.unsika.ac.id
Abstract

This study aims to determine the effect of premiums, claims and investment returns on the profits of Islamic life insurance companies in 2014-2019. The population used in this study is a sharia life insurance company registered with the Otoritas Jasa Keuangan (OJK) in the period 2014-2019 with a sampling method using purposive sampling techniques and gotted 9 sharia life insurance company samples were obtained that met the criteria for determining the sample. The data analysis method used in this study is multiple linear regression. The results of this study indicate that premiums have a positive effect on earnings, claims have no effect on earnings and investment returns have a positive effect on earnings.

\begin{abstract}
Abstrak
Penelitian ini bertujuan untuk mengetahui bagaimana pengaruh dari premi, klaim dan hasil investasi terhadap laba pada perusahaan asuransi jiwa syariah pada tahun 2014-2019. Populasi yang digunakan dalam penelitian ini adalah perusahaan asuransi jiwa syariah yang terdaftar di Otoritas Jasa Keuangan periode tahun 2014-2019 dengan metode pengambilan sampel menggunakan teknik purposive sampling dan di dapat 9 sampel perusahaan asuransi jiwa syariah yang memenuhi kriteria penentuan sampel. Metode analisis data yang digunakan dalam penelitian ini adalah regresi linear berganda. Hasil penelitian ini menunjukkan bahwa premi memiliki pengaruh yang positif terhadap laba, klaim tidak memiliki pengaruh terhadap laba dan hasil investasi memiliki pengaruh yang positif terhadap laba.
\end{abstract}

Fakultas Ekonomi, Universitas Singaperbangsa Karawang, Karawang, Indonesia ${ }^{2}$ 


\section{PENDAHULUAN}

Asuransi berperan penting pada era globalisasi saat ini untuk memproteksi risiko tidak terduga. Asuransi berbasis syariah lebih diminati oleh penduduk Indonesia yang mayoritas beragama islam, dilihat dari ekspektasi OJK bahwa pertumbuhan aset dari asuransi syariah lebih tinggi sebesar dari asuransi secara keseluruhan, aset asuransi syariah mencapai Rp. 41,96 triliun pada tahun 2018 dengan aset terbesar berasal dari asuransi jiwa syariah sebesar Rp. 34,37 triliun (CNN 2020). Melalui aset dan laba dalam satu periode pengamat keuangan dapat menilai kinerja perusahaan secara keseluruhan. Perang dagang yang terjadi pada tahun 2018 mempengaruhi pergerakan saham dan berdampak pada penurunan hasil investasi industri asuransi jiwa yang berimbas pada perolehan laba perusahaan asuransi jiwa. Banyak faktor yang mempengaruhi laba perusahaan asuransi termasuk pendapatan premi, beban klaim dan hasil investasi perusahaan.

Berdasarkan kesepakatan peserta asuransi wajib memenuhi pembayaran premi untuk mendapatkan perlindungan atas risiko yang terjadi. Besarnya jumlah premi yang diterima mempengaruhi besarnya jumlah dana yang akan diinvestasikan oleh perusahaan, dan akan menentukan besarnya keuntungan perusahaan. Perusahaan memiliki kewajiban untuk memenuhi hak peserta dalam bentuk pembayaran klaim jika terjadi risiko, besarnya jumlah klaim yang dipenuhi oleh perusahaan menunjukkan bahwa perusahaan mampu menjaga komitmennya terhadap peserta asuransi. Pendapatan asuransi syariah banyak berasal dari kegiatan investasi, dari investasi tersebut terdapat bagian untuk perusahaan selaku pengelola dana sesuai dengan perjanjian.

Hasil dari meneliti pengaruh premi, klaim, dan hasil investasi terhadap laba menunjukan hasil yang berbeda. Menurut Wulandari et al., (2019); Fauzi (2018) premi dan hasil investasi mempengaruhi laba dan klaim tidak mempengaruhi laba. Sedangkan menurut Reschiwati (2019) bahwa premi tidak mempengaruhi laba perusahaan dan klaim mempengaruhi laba.

Penelitian ini bertujuan untuk mengetahui peran premi, klaim, dan hasil investasi dalam mempengaruhi laba perusahaan yang bergerak pada bidang asuransi jiwa syariah di Indonesia pada tahun 2014-2019. Penelitian ini diharapkan dapat memberikan tambahan teori berupa bukti empiris mengenai pengaruh premi, klaim dan hasil investasi. Penelitian ini juga diharapkan mampu menjadi referensi dalam lingkungan akademis, saran pemikiran mengenai laba perusahaan asuransi jiwa syariah dan membantu pemilik perusahaan, manajer dan investor dalam pengambilan keputusan. Investor dapat mengetahui bahwa suatu perusahaan memiliki laba yang berkualitas dan penyajian aktiva yang tidak overstate melalui laporan keuangan yang berasal dari manajer.

$$
\text { Menurut Puspitasari }
$$
menyatakan bahwa keuangan dalam asuransi jiwa dengan prinsip syariah dikelola dengan sistem pemisahan dana atau split fund, dalam sistem ini aset dan liabilitas kelompok dana tabbaru dipisahkan dengan aset dan liabilitas kelompok dana perusahaan. 
Asuransi jiwa dengan prinsip syariah merupakan pertanggungan risiko yang berbentuk kerjasama atau perjanjian untuk saling menolong dalam meminimilkan berbagai macam risiko, seperti risiko kematian, kesehatan, dan kecelakaan yang dijalankan sesuai dengan ajaran agama islam tanpa unsur penipuan, judi dan riba. (Nopriansyah, 2016)

Efisiensi perusahaan dapat diukur melalui laba, karena laba berisi perolehan bersih dari keuntungan perusahaan tersebut. Menurut Hanum (2009) prinsip mudharabah (sistem bagi hasil) digunakan perusahaan asuransi syariah dalam pembagian perolehan laba berdasarkan perjanjian, laba tersebut didapat dari perolehan kontribusi peserta dan hasil dari kegiatan investasi.

Menurut Bayinah (2017) untuk mengikat kewajiban perusahaan sebagai pengelola dana dalam memberikan klaim, peserta wajib membayar atau mengumpulkan kontribusi atau premi sesuai ketentuan, dan disetujui oleh pemegang polis untuk dibayarkan berdasarkan perjanjian.

Klaim adalah pembayaran santunan oleh perusahaan kepada peserta atau ahli waris sesuai dengan isi akad yang telah doperjanjikan. Hak peserta tersebut diperoleh setelah peserta asuransi memenuhi kewajiban pembayaran premi (Nopriansyah, 2016).

Menurut Bayinah (2017), hasil investasi merupakan hasil yang didapat dari pengelolaan dana peserta berupa dana tabbaru dan tabungan yang dilakukan oleh perusahaan sebagai pengelola. Hasil investasi dari dana tabbaru seluruhnya akan dijadikan sebagai penambah dana tabbaru atau sebagiannya akan ditambahkan ke dalam dana tabbaru, dan sebagian dari lainnya diberikan kepada peserta dan atau kepada entitas pengelola sesuai dengan akad yang disepakati.

Tabbaru disebut juga hibah, sebagaimana definisinya bahwa yang dimaksud dengan hibah adalah ber tabbaru (berderma) dengan harta untuk kemaslahatan orang lain. Dana tersebut bukan menjadi milik pengelola sehingga tidak terjadi transfer of capital, pengelola hanya sebagai pengumpul dana atau pooling of capital (Bayinah, 2017).

Dalam PSAK 108, bagian dari dana tabbaru dalam dana peserta didalamnya terdapat kontribusi atau premi yang dibayarkan oleh peserta. Dana peserta terdiri dari dana tijarah, dana tabbaru dan cadangan surplus underwriting. Dana yang dikelola oleh perusahaan adalah premi yang terdapat dalam dana tabbaru dan sebagai pengelola perusahaan berhak menerima imbalan sesuai dengan persetujuan kesepakatan. Berdasarkan penjelasan tersebut, dapat dirumuskan hipotesis penelitian, yaitu:

H1: Premi berpengaruh terhadap laba

Dalam teori PSAK 108, hak dari peserta asuransi yang wajib dibayarkan oleh perusahaan sebagai pengelola dana peserta adalah klaim, yang dibayarkan perusahaan sesuai akad yang telah disepakati pada awal perjanjian. Pembayaran klaim harus dipenuhi guna menjaga kepercayaan dan komitmen perusahaan kepada seluruh peserta asuransi. Dari penjelasan tersebut, dapat dirumuskan hipotesis penelitian, yaitu:

H2 : Klaim berpengaruh terhadap laba.

Dalam PSAK 108 menyatakan bahwa hasil investasi dana tabbaru dapat merubah 
saldo dana tabbaru. Kontribusi dari peserta atau premi inilah yang digunakan dalam kegiatan investasi, dana tabbaru diinvestasikan pada instrumen investasi yang juga berbasis syariah, besarnya jumlah dana kontribusi yang diinvestasikan akan mempengaruhi perolahan keuntungan dari dana investasi tersebut. Dari penjelasan tersebut, dapat dirumuskan hipotesis penelitian yaitu:

H3 : Hasil investasi berpengaruh terhadap laba.

Dari penjabaran sebelumnya, dalam teori PSAK 108 dapat diketahui bahwa premi, klaim dan hasil investasi mempunyai pengaruh terhadap laba. Maka dapat dirumuskan hipotesis penelitian sebagai berikut:

H4 : Premi, klaim dan hasil investasi berpengaruh terhadap laba.

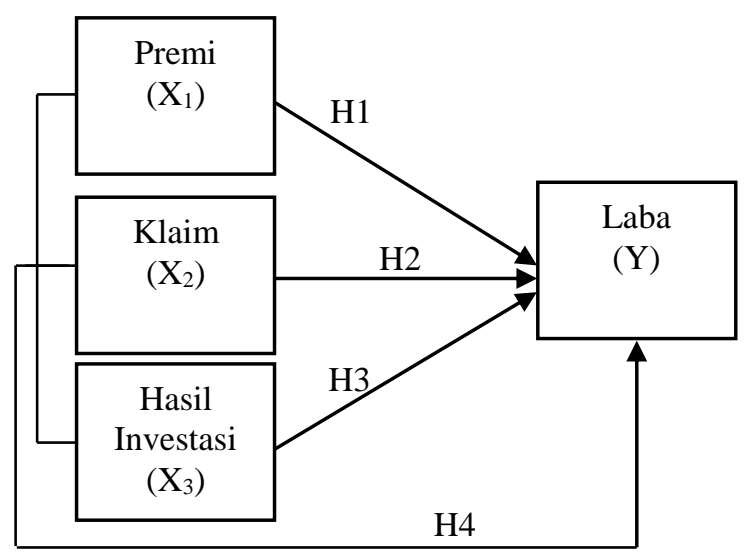

Sumber: dikaji dari berbagai sumber, 2020

Gambar 1.

Paradigma Penelitian

\section{METODE PENELITIAN}

Penelitian ini menggunakan desain atau tipe penelitian adalah asosiatif dengan pendekatan kuantitatif. Penelitian ini dilakukan di OJK (Otortitas Jasa Keuangan) yang memberikan informasi mengenai statistik perasuransian pada situs resminya di www.ojk.go.id dan di website resmi masingmasing perusahaan asuransi jiwa syariah yang memberikan informasi laporan keuangan tahunan.

Dalam penelitian ini menggunakan variabel sebagai berikut: Variabel dependen (Y) adalah laba. Dan variabel independen (X) adalah premi, klaim dan hasil investasi

Penelitian ini menggunakan data kuantitatif yang berupa data laporan keuangan tahunan. Dan berupa data sekunder yang berasal dari laporan keuangan tahunan perusahaan asuransi jiwa syariah yang diperoleh melelui website resmi masing-masing perusahaan.

Populasi yang digunakan adalah 24 perusahaan asuransi jiwa syariah yang terdaftar di OJK periode 2014-2019. Pengambilan sampel ditentukan menggunakan teknik purposive sampling dengan kriteria sebagai berikut: 1). Perusahaan yang berada di Indonesia dan mempunyai izin usaha serta terdaftar di OJK. 2). Memiliki laporan keuangan yang rutin dipublikasikan pada website resmi pada periode pengamatan tahun 2014-2019. 3). Perusahaan yang mendapatkan keuntungan atau laba pada periode pengamatan tahun 2014-2019. 4). Laporan keuangan perusahaan yang lengkap menyediakan data yang dibutuhkan dalam penelitian seperti data premi, data klaim, data hasil investasi dan data laba dalam laporan keuangan periode tahun 2014-2019. Dari pertimbangan tersebut maka diperoleh 9 perusahaan asuransi jiwa 
syariah yang memenuhi kriteria penentuan sampel.

Metode analisis data yang digunakan dalam penelitian ini dilakukan dengan analisis deskriptif, uji asumsi klasik (uji normalitas, uji multikolinearitas, uji autokorelasi, uji heteroskedastisitas), regresi linear berganda, uji hipotesis dan uji koefisien determinasi (R2) (Ghozali, 2016; Sugiyono, 2017).

HASIL DAN PEMBAHASAN
Tabel 2.

Hasil Uji Normalitas dengan Kolmogorov-Smirnov

\begin{tabular}{ll}
\hline & $\begin{array}{l}\text { Unstandardized } \\
\text { Residul }\end{array}$ \\
\hline $\mathrm{N}$ & 54 \\
Kolmogrov-Smirnov Z & 1,125 \\
Asymp. Sig. (2-tailed) &, 159 \\
\hline
\end{tabular}

Sumber: Data diolah peneliti, 2020

Hasil uji normalitas dengan menggunakan Kolmogorov-Smirnov menunjukan nilai Asymp. Sig. (2-tailed)

Tabel 1.

Hasil Analisis Deskriptif

\begin{tabular}{lllll}
\hline & Minimum & Maximum & Mean & Std. Deviation \\
\hline Premi (X1) & 4354 & 2554158 & 476575,11 & 686774,292 \\
\hline Klaim (X2) & -506818 & 328477 & 25074,07 & 156158,915 \\
\hline Hasil Investasi (X3) & 63 & 227477 & 23395,87 & 44613,005 \\
\hline Laba (Y) & 1487 & 1033318 & 161522,35 & 268364,081 \\
\hline Sumber: Data diolah & & &
\end{tabular}

Sumber: Data diolah peneliti, 2020

Hasil analisis deskriptif variabel dependen laba memperoleh nilai mean sebesar 161522,35 dengan nilai standar deviasi 268364,081, besarnya nilai maximum 1033318 dan nilai minimum 1487. Dan variabel independen premi memperoleh nilai mean sebesar 476575,11, dengan nilai standar deviasi 686774,29 , besarnya nilai maximum 2554158 dan nilai minimum 4354. Variabel independen klaim memperoleh nilai mean sebesar 25074,07, dengan nilai standar deviasi 156158,915 , besarnya nilai maximum 328447 dan nilai minimum -506818. Dan variabel independen hasil investasi memperoleh nilai mean sebesar 23395,87, dengan nilai standar deviasi 44613,005, besarnya nilai maximum 227477 dan nilai minimum 63. sebesar 0,159 yang artinya data terdistribusi normal, karena nilai signifikan lebih dari 0,05 .

Tabel 3.

Hasil Uji Multikolinaeritas

\begin{tabular}{llll}
\hline \multicolumn{2}{l}{ Model } & & \multicolumn{2}{c}{ Collinearity Statistics } \\
\cline { 3 - 4 } & & Tolerance & VIF \\
\hline \multirow{2}{*}{1} & Premi &, 765 & 1,307 \\
& Klaim &, 878 & 1,139 \\
& Hasil Investasi &, 861 & 1,162 \\
\hline
\end{tabular}

Sumber: Data diolah peneliti, 2020

Hasil multikolinearitas menunjukkan nilai tolerance pada variabel premi $\left(\mathrm{X}_{1}\right)$ sebesar 0,765>0,10 dan nilai VIF sebesar $1,307<10$, pada variabel klaim $\left(\mathrm{X}_{2}\right)$ nilai tolerance sebesar $0,878>0,10$ dan nilai VIF sebesar $1,139<10$, dan pada variabel hasil investasi nilai tolerance sebesar $0,861>0,10$ 
dan nilai VIF sebesar $1,162<10$. Dengan demikian dapat diketahui bahwa dalam penelitian ini tidak terjadi multikolinearitas.

Tabel 4.

Hasil Uji Autokorelasi

\begin{tabular}{ll}
\hline Model & Durbin-Watson \\
\hline 1 & 1,816
\end{tabular}

Sumber: Data diolah peneliti, 2020

Hasil uji autokorelasi diketahui nilai Durbin-Watson (DW) sebesar 1,816. Jika dibandingkan dengan nilai signifikansi $5 \%$ jumlah data $(\mathrm{N})=54$ dengan jumlah variabel independen $(\mathrm{K})=3$ maka diperoleh $\mathrm{dL}$ sebesar 1,446 dan nilai dU sebesar 1,680, nilai $4-\mathrm{dL}=2,554$ dan nilai $4-\mathrm{dU}=2,320$. Nilai DW 1,816 terletak diantara dU 1,680 dan $4-\mathrm{dU}=2,320$ sehingga dapat disimpulkan bahwa tidak terjadi autokorelasi.

Grafik scatterplot menunjukan titiktitik menyebar di atas dan di bawah angka 0 dengan pola penyebaran yang tidak jelas. Sehingga dapat diketahui bahwa tidak terjadi heteroskedastisitas.

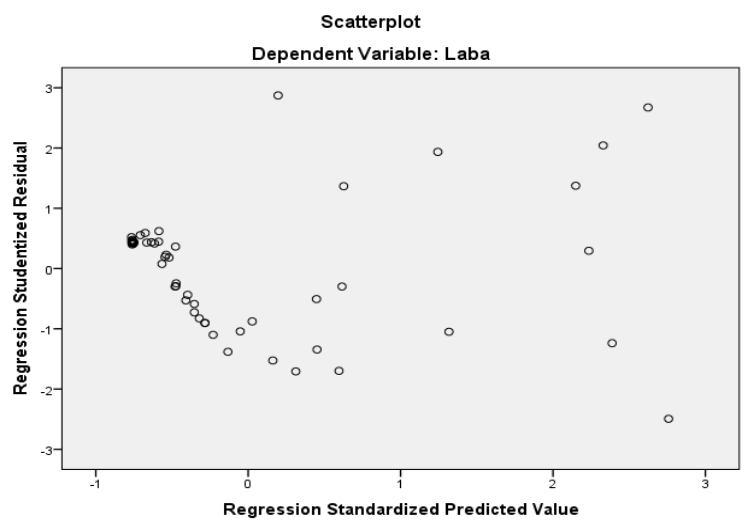

Sumber: Data diolah peneliti 2020

Gambar 2.

Hasil Uji Heteroskedastisitas
Tabel 5.

Uji Analisis Regresi Berganda

\begin{tabular}{lll}
\hline \multicolumn{1}{c}{ Model } & & \multicolumn{1}{c}{ B } \\
\hline \multirow{4}{*}{1} & (Constant) & $-33593,841$ \\
& Premi &, 337 \\
& Klaim &, 150 \\
& Hasil Investasi & 1,324 \\
\hline
\end{tabular}

Sumber: Data diolah peneliti 2020

Persamaan analisis regresi linear berganda sebagai berikut:

$$
\begin{aligned}
& \operatorname{Laba}(Y)=-33593,841+0,337 X_{1}+ \\
& 0,150 X_{2}+1,324 X_{3}+e \ldots \ldots \ldots \ldots \ldots
\end{aligned}
$$

Nilai konstanta sebesar $-33593,841$, artinya jika variabel independen bernilai 0 maka variabel dependen bernilai sebesar -33593,841. Premi memperoleh nilai 0,337, apabila premi meningkat sebesar $1 \%$, maka laba akan meningkat sebesar 0,337. Klaim memperoleh nilai 0,150 , artinya apabila klaim meningkat sebesar 1\%, maka laba akan meningkat sebesar 0,150. Hasil Investasi memperoleh nilai 1,324 , artinya apabila hasil investasi meningkat sebesar $1 \%$, maka laba akan meningkat sebesar 1,324.

Tabel 6.

Hasil Uji Parsial (Uji t)

\begin{tabular}{llll}
\hline Model & & $\mathrm{t}$ & Sig. \\
\hline \multirow{4}{*}{1} & (Constant) & $-1,969$ &, 054 \\
& Premi & 15,555 &, 000 \\
& Klaim & 1,684 &, 098 \\
& Hasil Investasi & 4,215 &, 000 \\
\hline
\end{tabular}

Sumber: Data diolah peneliti 2020

Berdasarkan hasil uji parsial (uji t) dengan tingkat kesalahan 5\% (0,05), jumlah data $(\mathrm{N}) 54$, dan variabel independen (k) 3, 
maka nilai $\mathrm{df}=\mathrm{N}-\mathrm{k}-1$ atau $\mathrm{df}=54-3-1$ $=50$ dan diperoleh nilai $\mathrm{t}_{\text {tabel }}=\mathrm{t}(0,025 ; 50)=$ 2,009. Maka dapat membuat kesimpulan menerima atau menolak $\mathrm{H}_{0}$, sebagai berikut: Premi $\left(\mathrm{X}_{1}\right)$. Berdasarkan hasil uji hipotesis $\mathrm{t}$, premi memiliki thitung $15,555>t_{\text {tabel }} 2,009$ dengan nilai signifikansi $0,000<0,05$. Sehingga dapat disimpulkan bahwa $\mathrm{H}_{0}$ ditolak dan $\mathrm{H}_{1}$ diterima, yang artinya bahwa premi $\left(\mathrm{X}_{1}\right)$ berpengaruh terhadap laba $(\mathrm{Y})$

Klaim $\left(\mathrm{X}_{2}\right)$. Berdasarkan hasil uji hipotesis $\mathrm{t}$, klaim memiliki thitung $1,684<\mathrm{t}_{\text {tabel }}$ 2,009 dengan nilai signifikansi $0,098>0,05$. Sehingga dapat disimpulkan bahwa $\mathrm{H}_{0}$ diterima dan $\mathrm{H}_{2}$ ditolak, yang artinya bahwa klaim $\left(\mathrm{X}_{2}\right)$ tidak berpengaruh terhadap laba (Y).

Hasil Investasi $\left(\mathrm{X}_{3}\right)$.Berdasarkan hasil uji hipotesis $t$, hasil investasi memiliki $t_{\text {hitung }}$ sebesar $>t_{\text {tabel }} 2,009$ dengan nilai signifikansi sebesar $0,000<0,05$. Sehingga dapat disimpulkan bahwa $\mathrm{H}_{0}$ ditolak dan $\mathrm{H}_{3}$ diterima, yang artinya bahwa hasil investasi $\left(\mathrm{X}_{3}\right)$ berpengaruh terhadap laba $(\mathrm{Y})$.

Tabel 7.

Hasil Uji Simultan (Uji f)

\begin{tabular}{llll}
\hline Model & F & Sig. \\
\hline 1 & Regression & 125,460 &, 000 \\
& Residual & & \\
& Total & & \\
\hline
\end{tabular}

\section{Sumber: Data diolah peneliti, 2020}

Tingkat kesalahan 5\% $(0,05)$, jumlah data (N) 54, dan jumlah variabel independen (k) 3 maka nilai $\mathrm{df}=\mathrm{N}-\mathrm{k}$ atau $\mathrm{df}=54-3=$ 51 , dan diperoleh nilai $f_{\text {tabel }}=(3 ; 51)=2,79$. Berdasarkan uji simultan (uji f), diketahui nilai $\mathrm{f}_{\text {hitung }} 125,460>\mathrm{f}_{\text {tabel }} 2,79$ dengan nilai signifikansi $0,000<0,05$. Sehingga dapat diketahui bahwa premi, klaim, dan hasil investasi berpengaruh terhadap laba.

Tabel 8.

Hasil Uji Koefisien Determinasi $\left(\mathbf{R}^{\mathbf{2}}\right)$

\begin{tabular}{ll}
\hline Model & $\begin{array}{l}\text { Adjusted } \\
\text { R Square }\end{array}$ \\
\hline 1 &, 876 \\
\hline
\end{tabular}

Sumber: Data diolah peneliti, 2020

Berdasarkan hasil uji koefisien determinasi $\left(\mathrm{R}^{2}\right)$ pada tebel 4.9 diperoleh nilai koefisien determinasi atau adjusted $\mathrm{R}$ square adalah sebesar 0,876 atau sama dengan 87,6\% yang berarti bahwa premi, klaim, dan hasil investasi memiliki kemampuan dalam menjelaskan dan mempengaruhi laba adalah sebesar $87,6 \%$ dan sisanya $12,4 \%$ dijelaskan dan dipengaruhi oleh faktor lain yang tidak dimasukkan dalam penelitian.

Pengaruh Premi terhadap Laba. Dari hasil pengujian hipotesis diketahui bahwa $\mathrm{H}_{0}$ ditolak dan $\mathrm{H}_{1}$ diterima yang berarti premi berpengaruh terhadap laba pada perusahaan asuransi jiwa syariah di Indonesia tahun 2014-2019. Kontribusi dari seluruh peserta asuransi diakui sebagai bagian dari dana tabbaru' dalam dana peserta (Bayinah, 2017). Dana tabbaru' tersebut kemudian dikelola oleh perusahaan dalam bentuk investasi dan perusahaan berhak menerima imbalan dari pengelolaan dana tersebut berdasarkan kesepakatan yang telah ditetapkan sebelumnya. Maka, semakin besar kontribusi atau premi yang didapat perusahaan akan berdampak pada besarnya hasil dari investasi dana tabbaru' dan tentu akan mempengaruhi peningkatan laba yang diperoleh perusahaan 
asuransi. Hasil penelitian ini sejalan dengan penelitian yang dilakukan oleh Sastri et al., (2017) yang menyatakan bahwa premi berpengaruh positif terhadap laba.

\section{Pengaruh Klaim terhadap Laba.}

Berdasarkan hasil pengujian hipotesis diketahui bahwa $\mathrm{H}_{0}$ diterima dan $\mathrm{H}_{2}$ ditolak yang berarti klaim tidak berpengaruh terhadap laba pada perusahaan asuransi jiwa syariah di Indonesia tahun 2014-2019. Pembayaran klaim dalam asuransi berbasis syariah diambil dari dana tabbaru' semua peserta dan hasil investasi. Oleh karena itu, pembayaran klaim merupakan pengurangan dari dana tabbaru' dan menjadi beban underwriting. Hasil penelitian ini sejalan dengan penelitian yang dilakukan oleh Wulandari et al., (2019) yang menyatakan bahwa klaim tidak berpengaruh terhadap laba.

Pengaruh Hasil Investasi terhadap Laba. Berdasarkan hasil pengujian hipotesis diketahui bahwa $\mathrm{H}_{0}$ ditolak dan $\mathrm{H}_{3}$ diterima yang berarti hasil investasi berpengaruh terhadap laba. Hasil dari investasi dana tabbaru seluruhnya akan menjadi penambah dana tabbaru atau sebagiannya menjadi penambah dana tabbaru, dan sebagian dari lainnya diberikan kepada peserta dan atau kepada entitas pengelola sesuai dengan akad yang disepakati (Bayinah, 2017). Perusahaan asuransi akan menerima imbalan atau ujroh atas pengelolaan dana, hal tersebut tentu akan mempengaruhi laba perusahaan yang menjadi meningkat. Hasil penelitian ini sejalan dengan penelitian yang dilakukan oleh Larasati (2018) yang menyatakan bahwa investasi berpengaruh positif terhadap laba.

\section{SIMPULAN DAN SARAN}

Berdasarkan uji parsial (uji t) dapat disimpulkan bahwa premi berpengaruh terhadap laba, klaim tidak berpengaruh terhadap laba dan hasil investasi berpengaruh terhadap laba perusahaan asuransi jiwa syariah tahun 2014-2019. Berdasarkan uji simultan (uji f) dapat disimpulkan bahwa premi, klaim dan hasil investasi berpengaruh terhadap laba pada perusahaan asuransi jiwa syariah tahun 2014-2019.

Perusahaan asuransi diharapkan untuk dapat mempertahankan dan tetap berupaya dalam meningkatkan kegiatan investasinya supaya perolehan laba terus meningkat. Dengan tujuan untuk keberlangsungan hidup perusahaan dimasa mendatang. Perusahaan asuransi perlu melakukan pengelolaan manajemen underwriting yang lebih baik agar dapat menyeleksi risiko dan menentukan tarif premi yang telah disesuaikan dengan risiko yang akan ditanggung oleh perusahaan, agar beban klaim yang ditanggung perusahaan tidak akan terlalu besar mempengaruhi cadangan dana tabbaru' yang dimiliki perusahaan, sehingga perusahaan dapat memperoleh laba yang optimal. Untuk peneliti selanjutnya diharapkan dapat melakukan penelitian dengan menambahkan variabel, jumlah perusahaan dan periode pengamatan.

\section{REFERENSI}

Bayinah, Ai Nur. (2017). Role of Zakat as Social Finance Catalyst to Islamic Banking and Economic Growth. International Journal of Zakat. 2(2), 55-70. https://doi.org/10.37706/ijaz.v2i2.25.

CNN. (2020). Industri Asuransi Syariah Optimistis 
Pengaruh Premi, Klaim dan Hasil Investasi Terhadap Laba Pada... Nia Anggraina Zen \& Gusganda Suria Manda

Aset Tumbuh 14,76 Persen. CNN Indonesia. https://m.cnnindonesia.com/ekonomi/2019051 7200737-78-395891/industri-asuransi-syariahoptimistis-aset-tumbuh-1476-persen.

(Diunduh tanggal 02 April 2020)

Fauzi, Achmad. (2018). Pengaruh Pendapatan Premi Asuransi Dan Hubungannya Dengan Beban Klaim Terhadap Laba Bersih Perusahaan (Studi Kasus Pada PT. Jasa Raharja). Jurnal Ilmiah Akuntansi Peradaban. 4 (1). 164-180. https://doi.org/10.24252/jiap.v4i1.5676.

Ghozali, Imam. (2016). Aplikasi Analisis Multivariate Dengan Program IBM SPSS 23. Semarang: BPFE Universitas Diponegoro.

Ikatan Akuntan Indonesia. (2008). PSAK No. 108 Tentang Akuntansi Transaksi Asuransi Syariah.

Larasati, Auliya. (2018). "Pengaruh Kontribusi Peserta (Premi), Klaim, Hasil Investasi Dan Underwriting Terhadap Laba Perusahaan Asuransi Jiwa Syariah Di Indonesia Periode 2012-2016." (Skripsi). Lampung: Universitas Islam Negeri Raden Intan.

Nopriansyah, Waldi. (2017). Pendekatan Akad Murabahah Di Perbankan Syariah Secara Normatif. Yogyakarta: CV. Andi Offset.

Puspitasari, Novi. (2015). Hybrid Contract and Funds Efficiency Management of Islamic General Insurance Company (Study In Indonesia). Procedia-Social and Behavioral Sciences. 2(11), 260-267. 10.1016/j.sbspro.2015.11.033.

Reschiwati, \& Rizki Putri Solikhah. (2018). Influence Of Incoming Premium, Claim Cost And Underwriting Results On Net Income In Insurance Company In Indonesia: Case Study Of Insurance Company Listen On Indonesia Stock Exchange. Internasional Jurnal of Modern Trends in Business Research. 1(3). 01-17. http://www.ijmtbr.com

Sastri, I. A. I, Edy Sujana, \& Ni Kadek Sinarwati. (2017). Pengaruh Pendapatan Premi, Hasil Underwriting, Hasil Investasi Dan Risk Based Capital Terhadap Laba Perusahaan Asuransi. E-Journal $S 1$ Ak Universitas Pendidikan Ganesha. 7(1),1-11. http://dx.doi.org/10.23887/jimat.v7i1.9409.

Sugiyono. (2017). Metode Penelitian Bisnis (Pendekatan Kuantitatif, Kualitatif, Kombinasi Dan R\&D). Bandung: Alfabeta.

Wulandari, Januarifah Rizqi, Wimbo Wiyono, \& Noviansyah Rizal. (2019). Pengaruh Premi, Klaim, Investasi, Dan Underwriting Terhadap Laba Perusahaan Asuransi Jiwa Syariah Di
Indonesia Periode Tahun 2013 - 2017. Proceedings Progress Conference. 2(1). 7985. http://dx.doi.org/10.29313/.v0i0.19604.

Zulia Hanum. (2009). Pengaruh Hutang Terhadap Laba Usaha Pada Pusat Penelitian Karet Tanjung Morawa Sumatera Utara. Jurnal Ilmiah Kultura. 1(1), 37-45. http://jurnal.umsu.ac.id. 